A defect which inheres in Mr. Bullock's method is that his book lacks consistency, in the sense of logical coherence. Rent, wages, interest, and profits are at the back of the book, as seemingly they just as well may or may not be. The truth appears to be that to elementalize economics, so to speak, by taking the theoretical backbone out of it, cannot fail to leave the subject formless and flabby. But this is the old problem of what to do in an elementary book. At all events, so far as the book is doctrinal at all, it is admirahly sound and judicial. To one who reads between the lines it is evident also that Mr. Bullock is a master of the science, is fully conversant with its most progressive thought, and is thoroughly in sympathy therewith. As a whole the book deserves no small praise. But it is too long -480 pages.

H. J. Davenport.

Supplément au Nouveau Dictionnaire d'Économie Politique de M. Léon Say et Josephe Chailley-Bert. Paris: Guillaumin \& Cie., 1897. Roy. 8vo. pp. 27 I.

This supplement takes the place of a second edition of M. Say's Dictionary. The correction of errors and the addition of necessary articles in the form of a supplement have saved the purchasers of the Dictionary the necessity of buying a second entire edition. Such a regard for the early buyer is as commendable as it is rare.

M. Chailley-Bert informs us that M. Say, in the entire Dictionary, as well as in the supplement, had in the main the oversight of the list of articles, choosing the writers, reading the manuscripts, and reviewing the proofs. The supplement adds, among others, necessary biographical articles on Bagehot, Baudrillart, Cairnes, Courcelle-Seneuil, Cournot, Dunoyer, Fawcett, D. Hume, Jevons, Cliffe Leslie, Mangoldt, Marlo, Moeser, Thorold Rogers, Roscher, and Léon Say. Other needed articles are those on Anarchie, Anti-Sémitisme, Circulation monétaire, Crédit agricole and Credit foncier (by Ives Gyot), École anglaise (by H. Higgs), Nihilisme, and Placement.

This last work in the very distinguished career of M. Say bids us pause to express our respect for his life and economic activity. The bibliography (p. 267) of some fifty titles shows an amazing productiveness during his seventy years (1826-1896). Contrary to the dictum of some wise observers that a writer's chief productive period is from thirty to forty, M. Say's greatest activity seems to have been reached after he 
was fifty. He first assumed high office as minister of finance under Thiers (December $7,187_{2}$ ), and then conducted the greatest exchange operation of the century, arising out of the transfer of the war idemnity from France to Germany. It was managed with signal ability. $\mathrm{He}$ was the finance minister par excellence, and six times again was he given the portfolio. In our country this would have been impossible; and his career is worthy of reflection because, coming of an economic ancestry, thoroughly trained in economics, he lived in a country where statesmen are drawn from the ranks of educated men, and in which a public career in his chosen field was open to him. The examples of Léon Say, Miquel, de Witte, and many others in European bureaus of finance, show how special scholarship and ability have caused men to be called to the service of the state. In the case of $\mathrm{M}$. Say we find that from 1872 to 1882 he practically directed the financial policy of France. In 1876 he was chosen a senator, in 1880 was made president of the senate, and in 1886 was elected to the French Academy. Surely France has appreciated her men of education and ability.

J. Laurence Laughlin.

\section{Die Währungsfrage in den Vereinigten Staaten von Nordamerika.} By Max Prager. Stuttgart: J. G. Cotta'sche Buchhandlung, I 897. 8vo, pp xii +476 .

THIs work, which forms one number of the economic studies of the University of Munich, aims at presenting in succinct form the history of the question of the standards in the United States. The work is throughout descriptively historical in its nature; at times the reader is tempted to wish that more positive statements, by way of giving the author's conclusions as to the significance of certain periods, were put forth.

The author, who is frankly an adherent of the gold standard, looks at American precedents, having in view the bearing they have upon German conditions. He justifies his investigation by stating that the Americans have left untried no thinkable system of standard, and in this particular he regards the United States, as did Bagehot, as the widest field of investigation in which the old findings of economic experience are again put to the test.

He divides his investigation into three portions: the period of the legal double standard, I792-1873; the paper standard and the 